\title{
Pendidikan Karakter Religius dan Mandiri di Pesantren
}

\author{
Dian Popi Oktari' ${ }^{1}$, Aceng Kosasih ${ }^{2}$ \\ 1 dianpopi@upi.edu \\ ${ }^{1}$ Universitas Pendidikan Indonesia
}

Submitted

January 14, 2019

\section{Revised}

June 24, 2019

http://dx.doi.org/10.17509/jpis.v28i1.14985
Accepted

June 25, 2019

\begin{abstract}
Pesantren are the oldest Islamic educational institutions and have become part of national education. Pesantren have contributed greatly to the growth and development of the Nusantara Islam and at the same time the growth of other Islamic institutions in Indonesia. Pesantren's education holds distinctive characters including religius characters and independent characters. This research was conducted at Manarul Huda Cottage, located in Bandung. This study aims to find out how Pesantren instill religious character and independent character in their santri. The researcher used a descriptive qualitative method to identify character education in the Manarul Huda Islamic Boarding School. The results of the study show that the Manarul Huda Islamic boarding school instills religius character through daily activities and independent character implanted through entrepreneurial activities.
\end{abstract}

Keywords: Character Education, Religius, Independent.

\section{ABSTRAK}

Pesantren merupakan lembaga Pendidikan Islam tertua dan telah menjadi bagian dari pendidikan nasional. Pesantren telah memberikan banyak kontribusi bagi pertumbuhan dan perkembangan Islam Nusantara dan sekaligus pemantik pertumbuhan lembaga-lembaga Islam lainnya di Indonesia. Pendidikan Pesantren menyimpan karakter khas antara lain karakter religius dan karakter mandiri. Penelitian ini dilakukan di Pondok Manarul Huda yang berlokasi di Bandung. Penelitian ini bertujuan untuk mengetahui bagaimana pesantren menanamkan karakter religius dan karakter mandiri pada santrinya. Peneliti menggunakan metode deskriptif kualitatif untuk mengidentifikasi pendidikan karakter di Pesantren Manarul Huda. Hasil penelitian menunjukkan bahwa pesantren Manarul Huda menanamkan karakter religius melalui aktivitas sehari-hari dan karakter mandiri ditanamkan melalui kegiatan kewirausahaan.

Keywords: Pendidikan Karakter, Religius, Mandiri.

\section{PENDAHULUAN}

Pendidikan Islam adalah pendidikan yang mempunyai suatu misi yaitu untuk membentuk pribadi muslim seutuhnya dengan mengembangkan seluruh potensi manusia baik secara jasmaniah maupun rohaniah, menumbuh suburkan hubungan yang harmonis antar setiap pribadi manusia dengan Allah SWT, manusia dengan 
manusia serta manusia dengan lingkungan atau alam.

Indonesia merupakan Negara yang mayoritas penduduknya beragama Islam terbesar kelima didunia. Hal itulah yang membuat pendidikan Islam berkembang pesat di Indonesia. Pendidikan Islam muncul dalam berbagai macam lembaga yang hampir ada disetiap kota-kota besar bahkan sampai kedaerah, salah satunya yaitu pesantren.

Pesantren merupakan bagian dari pendidikan nasional yang telah ada jauh sebelum kemerdekaan dan bahkan merupakan lembaga pendidikan yang memiliki kekhasan, keaslian (indigenous), dan kelndonesiaan. Oleh karenanya pesantren merupakan lembaga pendidikan Islam tertua yang memberikan banyak kontribusi bagi pertumbuhan dan perkembangan Islam Nusantara dan sekaligus pemantik pertumbuhan lembaga-lembaga pendidikan Islam lainnya di Indonesia.

Pesantren merupakan lembaga pendidikan Islam yang unik. Tidak saja karena keberadaannya yang sudah sangat lama, tetapi juga karena kultur, metode, dan jaringan yang diterapkan oleh lembaga agama tersebut. Karena keunikannya itu, menyebutnya sebagai subkultur masyarakat Indonesia (khususnya Jawa) [1]. Pada zaman penjajahan, pesantren menjadi basis perjuangan kaum nasionalis-pribumi. Banyak perlawanan terhadap kaum kolonial yang berbasis pada dunia pesantren.

Jiwa pondok pesantren

merupakan karakteristik yang belum pernah dibangun oleh sistem pendidikan manapun. Jiwa pondok pesantren itu terimplikasi dalam panca Jiwa Pondok Pesantren [2], yaitu:

1. Jiwa Keikhlasan

2. Jiwa Kesederhanaan
3. Jiwa Ukhuwah Islamiyah

4. Jiwa Kemandirian

5. Jiwa Bebas

Pesantren sebagai tempat pendidikan agama memiliki basis sosial yang jelas, karena keberadaannya menyatu dengan masyarakat. Pada umumnya, pesantren hidup dari, oleh, dan untuk masyarakat. Visi ini menuntut adanya peran dan fungsi pondok pesantren yang sejalan dengan situasi dan kondisi masyarakat, bangsa, dan negara yang terus berkembang. Sementara itu, sebagai suatu komunitas, pesantren dapat berperan menjadi penggerak bagi upaya peningkatan kesejahteraan masyarakat mengingat pesantren merupakan kekuatan sosial yang jumlahnya cukup besar. Secara umum, akumulasi tata nilai dan kehidupan spiritual Islam di pondok pesantren pada dasarnya adalah lembaga tafaqquh fid din (memiliki dan menguasai ilmu-ilmu agama) yang mengemban untuk meneruskan risalah Nabi Muhammad SAW sekaligus melestarikan ajaran Islam.

Sebagai sebuah lembaga, pesantren dimaksudkan untuk mempertahankan nilai-nilai keislaman dengan titik berat pada pendidikan. Pesantren juga berusaha untuk mendidik para santri yang belajar pada pesantren tersebut yang diharapkan dapat menjadi orang-orang yang mendalam pengetahuan keislamannya. Kemudian, mereka dapat mengajarkannya kepada masyarakat, di mana para santri kembali setelah selesai menamatkan pelajarannya di pesantren.

Pendidikan Pesantren memang menyimpan karakter yang cukup khas, tidak hanya dalam sistemnya, tetapi juga dalam perannya. Tujuan Utama Pendidikan Nasional menitik beratkan pada peningkatan ketaqwaan kepada Tuhan Yang Maha Esa, mempertinggi 
budi pekerti, memperkuat kepribadian dan mempertebal semangat kebangsaan dan cinta tanah air, hal ini sejalan dengan tujuan pendidikan Islam baik secara sosiologis maupun filosofis. Namun tujuan utama dari pendidikan nasional itu masih terbentur tembok besar bernama fakta dan realita yang menunjukkan kualitas lulusan lembaga pendidikan masih belum mencapai tujuan utama dari Pendidikan Nasional. Oleh karena itu banyak orang berpikir bahwa "sekolah saja" tidak mungkin dapat diandalkan untuk mendidik manusia secara utuh.

Banyak yang mengeluh bahwa akhlak dan prilaku pelajar dewasa ini cenderung merosot dengan berbagai bentuk tindakannya yang merisaukan banyak pihak. Karena itu, patut dipikirkan kemungkinan "pesantren masuk sekolah". Disinilah pendidikan Pesantren pasti akan diuji eksistensinya seputar ihwal apakah mampu menjadi alternatif dari kebutuhan tersebut. Serta akan semakin mengukuhkan kemampuan pesantren dalam mewujudkan kualitas manusia Indonesia seutuhnya.

Pondok Pesantren Manarul Huda Bandung merupakan salah satu pondok pesantren yang menerapkan pendidikan karakter dalam sistem pendidikannya. Pendidikan karakter di pesantren ini dilakukan dengan metode pembiasaan dan modeling dari kiyai dan para pengurusnya. Para santri dibiasakan melakukan kegiatan yang dapat membangun karakter baik mereka seperti sholat wajib berjamaah, mengaji, puasa, mempelajari kitab kuning, melaksanakan ibadah-ibadah sunnah lain, dan juga kegiatan kewirausahaan pesantren.

Karakter yang paling menonjol dalam pendidikan di Pesantren Manarul Huda Bandung adalah karakter religius dan karakter mandiri. Karakter religius tercermin dalam setiap kegiatan yang dapat meningkatkan keimanan pada Allah SWT. Selain itu, pihak pesantren juga membuat kegiatan kewirausahaan yang dapat membangun kemandirian santrinya terutama ketika mereka lulus dari pesantren.

Dari hasil pengamatan peneliti, pesantren Manarul Huda Bandung telah berhasil menanamkan karakter religius dan mandiri pada para santrinya. Hal tersebut dapat dilihat dari para alumni pesantren yang telah menjadi ustazd/ustadzah, membuka usaha mandiri, dan lain sebagainya.

\section{KAJIAN LITERATUR}

\section{A. Pendidikan Karakter}

Secara etimologis, kata karakter (Inggris: character) berasal dari bahasa Yunani (Greek), yaitu charassein yang berarti "to engrave". Kata "to engrave" bisa diterjemahkan mengukir, melukis, atau menggoreskan [3]. Kumpulan tata nilai yang menuju pada suatu sistem, yang melandasi pemikiran, sikap dan perilaku yang ditampilkan [4]. Dalam istilah bahasa Arab, karakter memiliki kemiripan makna dengan ahlak yaitu tabiat atau kebiasaan melakukan hal yang baik. Al-Ghazali menggambarkan bahwa akhlak adalah tingkah laku yang berasal dari hati yang baik. Oleh karena itu pendidikan karakter adalah usaha aktif untuk membentuk kebiasaan baik (habit), sehingga sifat anak sudah terukir sejak kecil [5].

Karakter terdiri dari tiga bagian yang saling terkait yaitu pengetahuan tentang moral (moral knowing), perasaan (moral feeling), dan perilaku bermoral (moral behaviour ) [6]. Karakter yang baik terdiri dari mengetahui kebaikan (knowing the good), mencintai atau menginginkan kebaikan (loving atau desiring the 
good), dan melakukan kebaikan (acting the good). Oleh karena itu, cara membentuk karakter yang efektif adalah dengan melibatkan ketiga aspek tersebut.

Menumbuhkan karakter yang merupakan the habit of mind, heart and action, yang antara ketiganya (pikiran, hati dan tindakan) adalah saling terkait [7]. Pendidikan Karakter adalah upaya mendorong peserta didik tumbuh dan berkembang dengan kompetensi berpikir dan berpegang teguh pada prinsip-prinsip moral dalam hidupnya serta mempunyai keberanian untuk melakukan yang benar meskipun dihadapkan pada berbagai tantangan [8].

Pendidikan karakter adalah sebuah proses transformasi nilai-nilai kehidupan untuk ditumbuh kembangkan dalam kepribadian seseorang, sehingga menjadi satu dalam perilaku kehidupan orang itu [9]. Oleh karena itu, pendidikan karakter merupakan proses internalisasi atau penanaman nilai-nilai positif kepada peserta didik agar mereka memiliki karakter yang baik (good character) sesuai dengan nilai-nilai yang dirujuk baik dari agama, budaya, maupun falsafah bangsa.

\section{B. Pondok Pesantren Sebagai Lembaga Pendidikan \\ Kata pondok berasal dari kata} Funduq yang berarti hotel atau asrama. Sedangkan dalam bahasa Indonesia mempunyai banyak arti, di antaranya adalah madrasah tempat belajar agama Islam. Sekarang lebih dikenal dengan nama pondok pesantren. Pesantren berasal dari kata santri yang dapat diartikan tempat santri. Kata santri berasal dari kata Cantrik (bahasa Sansekerta) yang berarti orang yang selalu mengikuti guru, yang kemudian dikembangkan oleh Perguruan Taman Siswa dalam sistem asrama yang disebut Pawiyatan. Istilah santri juga ada dalam bahasa Tamil, yang berarti guru mengaji. Istilah santri berasal dari istilah shastri, yang dalam bahasa India berarti orang yang tahu buku-buku suci agama Hindu atau seorang sarjana ahli kitab suci agama Hindu [10].

Pondok pesantren merupakan suatu lembaga pendidikan agama Islam yang tumbuh serta diakui masyarakat sekitar, dengan sistem asrama (komplek), dimana santri menerima pendidikan agama melalui sistem pengajian atau madrasah yang sepenuhnya berada dibawah kedaulatan dari leadership seorang atau beberapa orang kiai dengan ciri-ciri khas yang bersifat kharismatik serta independent dalam segala hal [11].

$$
\text { Pesantren pada mulanya }
$$

didirikan sebagai lembaga dakwah namun pada tahap selanjutnya menjadi lembaga pendidikan karena berdakwah melalui pendidikan dirasa cukup efisien dalam pesantren ada lima unsur yang tidak bisa dipisahkan dengan pesantren yaitu: adanya Kiai, ada pondok, ada masjid, ada santri dan ada pengajaran kitab kuning. Lima elemen ini adalah elemen-elemen yang tidak bisa dipisahkan dari pesantren dan ini menjadi ciri khas pendidikan pesantren [12]. Adapun peran pesantren yakni:

1. Sebagai pusat berlangsungnya transmisi ilmu-ilmu Islam tradisional,

2. Sebagai penjaga dan pemelihara keberlangsungan Islam tradisional, dan

3. Sebagai pusat reproduksi ulama.

Dari sekian banyak tipe pondok pesantren, dalam menyelenggarakan pendidikan dan pengajaran bagai para santrinya, secara garis besar dapat dikelompokkan ke dalam dua bentuk pondok pesantren: 
a. Pondok Pesantren Salafiyah, yaitu yang menyelenggarakan pengajaran Alquran dan ilmu-ilmu agama Islam, serta kegiatan pendidikan dan pengajarannya sebagaimana yang berlangsung sejak awal pertumbuhannya.

b. Pondok Pesantren Khalafiyah, yaitu pondok pesantren yang selain menyelenggarakan kegiatan pendidikan kepesantrenan, juga menyelenggarakan kegiatan pendidikan formal (sekolah atau madrasah).

Pendidikan pondok pesantren yang merupakan bagian dari Sistem Pendidikan Nasional memiliki 3 unsur utama yaitu:

1) Kyai sebagai pendidik sekaligus pemilik pondok dan para santri;

2) Kurikulum pondok pesantren;

3) Sarana peribadatan dan pendidikan, seperti masjid, rumah kyai, dan pondok, serta sebagian madrasah dan bengkel-bengkel kerja keterampilan.

Kegiatannya terangkum dalam “Tri Dharma Pondok pesantren” yaitu: 1) Keimanan dan ketaqwaan kepada Allah SWT; 2) Pengembangan keilmuan yang bermanfaat; dan 3) Pengabdian kepada agama, masyarakat, dan negara. Pondok pesantren sebagai sub-sistem pendidikan nasional dilndonesia merupakan bagian integral dari lembaga keagamaan yang secara unik memiliki potensi yang berbeda dengan lembaga pendidikan lainnya.

Hal ini sejalan dengan firman Allah dalam QS. Ali ImrAn (3): 102, sebagai berikut yang artinya:

"Hai orang-orang yang beriman, bertakwalah kepada Allah sebenarbenar takwa kepada-Nya; dan janganlah sekali-kali kamu mati kecuali dalam keadaan beragama Islam".
Orang tua juga dituntut untuk mempersiapkan anaknya sebagai anggota masyarakat yang baik, sebab masyarakat yang baik berasal dari individu-individu yang baik sebagai anggota dari suatu komunitas masyarakat itu sendiri. Mengenai hal ini, Allah Swt menegaskan dalam QS. ArRa'du (13:11,) yang artinya:

"Bagi manusia ada malaikatmalaikat yang selalu mengikutinya bergiliran, di muka dan di belakangnya, mereka menjaganya atas perintah Allah. Sesungguhnya Allah tidak mengubah keadaan sesuatu kaum sehingga mereka mengubah keadaan yang ada pada diri mereka sendiri. Dan apabila Allah menghendaki keburukan terhadap sesuatu kaum, maka tak ada yang dapat menolaknya; dan sekali-kali tak ada pelindung bagi mereka selain Dia" (ArRa'du, 13:11).

Ayat di atas menjelaskan bahwa upaya membangun budaya masyarakat harus dilakukan sejak dini, mengingat karakter manusia harus membiasakan apa yang harus dilakukan, maka pembiasaan baik juga perlu dilaksanakan. Oleh karena itu, pesantren memfasilitasi pembiasaan baik juga disiplin dalam mengikuti pengajian dan mandiri dalam melakukan seluruh kegiatan dan kebutuhan santrinya. Dengan demikian, individu yang baik akan muncul dari adanya pesantren ini juga meminimalisir kebiasaan buruk yang mungkin dimiliki oleh santri.

Peran pesantren dalam pendidikan Islam tertuang dalam pandangan berikut ini yang berkaitan dengan usaha menyukseskan misi dalam tiga macam tuntutan hidup seorang muslim yang dapat diimplementasikan dalam lembaga pendidikan Islam adalah sebagai berikut [13]: 
1. Pembebasan manusia dari ancaman api neraka, sesuai dengan perintah Allah :

Artinya: "Jagalah dirimu beserta keluargamu dari ancaman api neraka".

2. Pembinaan manusia menjadi hamba Allah Swt yang memiliki keselarasan dan keseimbangan hidup bahagia didunia dan diakhirat sebagai realisasi cita-cita orang yang beriman dan bertaqwa.

Artinya:"Wahai tuhanku, berilah aku kehidupan didunia yang sejahtera dan berilah kehidupan di akhirat yang bahagia dan jauhkanlah kami dari siksa api neraka".

3. Membentuk diri pribadi manusia yang memancarkan sinar keimanan yang kaya dengan ilmu pengetahuan, yang satu sama lain saling mengembangkan hidupnya untuk menghambakan dirinya kepada Khaliknya. Keimanan dikendalikan oleh akal budinya. Firman Allah :

Artinya :" Hai orang-orang yang beriman, apabila dikatakan kepadamu: "Berlapang-lapanglah dalam majelis", maka lapangkanlah, niscaya Allah akan memberi kelapangan untukmu. Dan apabila dikatakan: "Berdirilah kamu, maka berdirilah, niscaya Allah akan meninggikan orang-orang yang beriman di antaramu dan orangorang yang diberi ilmu pengetahuan beberapa derajat. Dan Allah Maha Mengetahui apa yang kamu kerjakan." (Al- Mujadalah, 58: 11)

\section{Nilai-Nilai Karakter dalam Pendidikan Pesantren \\ Pendalaman agama yang diajarkan dipesantren cukup}

menempatkan pada bentuk lembaga pendidikan Islam yang lebih membentuk afeksi santri agar terbentuk karakter manusia yang salih. Selain menanamkan pendidikan agama, pesantren juga menanamkan karakter sebagai berikut:

1. Religius

Kata religius berakar dari kata religi (religion) yang artinya taat, pada agama. Religius adalah kepercayaan atau keyakinan pada sesuatu kekuatan kodrati di ata kemampuan manusia. Jadi karakter religius dalam Islam adalah berperilaku dan berakhlak sesuai dengan apa yang diajarkan dalam pendidikan.

Seseorang untuk dapat dikatakan religius apabila dapat menampilkan aspek-aspek ajaran agama dalam kehidupannya baik secara eksplisit maupun secara implisit. Dalam memberikan kriteria religius, ada beberapa pandangan yang diberikan. Tiga kriteria religious [14], yaitu;

1) keterlibatan diri dengan yang Mutlak;

2) pengaitan perilaku secara sadar dengan sistem nilai yang bersumber dari yang Mutlak; dan

3) memasrahkan diri, hidup dan matinya, kepada yang Mutlak.

2. Mandiri

kemandirian merupakan suatu sikap yang memungkinkan sesorang berbuat bebas melakukan sesuatu atas dorongan diri sendiri untuk kebutuhan sendiri, mengejar prestasi, penuh ketekunan, serta berkeinginan untuk melakukan sesuatu tanpa bantuan orang lain, mampu berfikir dan bertindak kreatif dan penuh inisiatif, mampu mempengaruhi lingkungannya, mempunyai rasa percaya diri terhadap kemampuan diri sendiri, menghargai keadaan diri sendiri dan memperoleh keputusan dari usahanya [15]. 
Individu dikatakan mandiri apabila memiliki lima ciri sebagai berikut [16]:

1) percaya diri, adalah meyakini pada kemampuan dan penilaian diri sendiri dalam melakukan tugas dan memilih pendekatan yang efektif,

2) mampu bekerja sendiri, adalah usaha sekuat tenaga yang dilakukan secara mandiri untuk menghasilkan sesuatu yang membanggakan atas kesungguhan dan keahlian yang dimilikinya,

3) menguasai keahlian dan keterampilan yang sesuai dengan kerjanya, adalah mempunyai keterampilan sesuai dengan potensi yang sangat diharapkan pada lingkungan kerjanya,

4) menghargai waktu, adalah kemampuan mengatur jadwal sehari-hari yang diprioritaskan dalam kegiatan yang bermanfaat secara efesien, dan

5) tanggung jawab, adalah segala sesuatu yang harus dijalankan atau dilakukan oleh seseorang dalam melaksanakan sesuatu yang sudah menjadi pilihannya atau dengan kata lain, tanggung jawab merupakan sebuah amanat atau tugas dari seseorang yang dipercayakan untuk menjaganya.

Sejumlah faktor yang mempengaruhi perkembangan kemandirian, yaitu [17]:

a) Gen atau keturunan orang tua. Orang tua memiliki sifat kemandirian tinggi seringkali menurunkan anak yang memiliki kemandirian juga.

b) Pola asuh orang tua. Cara orang tua mengasuh dan mendidik anak akan mempengaruhi perkembangan kemandirian anak remajanya.

c) Sistem pendidikan di sekolah. Proses pendidikan di sekolah yang tidak mengembangkan demokrasi pendidikan dan cenderung menekankan indoktrinasi tanpa argumentasi akan menghambat perkembangan kemandirian remaja sebagai siswa.

d) Sistem kehidupan di masyarakat. Sistem kehidupan masyarakat yang terlalu menekankan pentingnya hirarki struktur sosial, merasa kurang aman atau mencekam serta kurang menghargai manifestasi potensi remaja dalamkegiatan produktif dapat menghambat kelancaran perkembangan kemandirian remaja atau siswa.

\section{METODE PENELITIAN}

Penelitian ini menggunakan metode deskriptif kualitatif. Tujuan dari penelitian deskriptif ini adalah untuk membuat deskripsi, gambaran, atau lukisan secara sistematis, faktual dan akurat mengenai fakta-fakta, sifat-sifat serta hubungan antarfenomena yang diselidiki. Sedangkan menurut [18] menyatakan bahwa metode deskriptif adalah suatu metode yang digunakan untuk menggambarkan atau menganalisis suatu hasil penelitian tetapi tidak digunakan untuk membuat kesimpulan yang lebih luas.

Teknik pengumpulan data yang digunakan dalam penelitian ini adalah wawancara, observasi dan dokumentasi yang dilakukan pada para pengurus dan santri-santri Pesantren Pondok Manarul Huda, Bandung.

\section{HASIL DAN PEMBAHASAN Implementasi Karakter Religius dan Mandiri Di Pesantren Manarul Huda}

Program pembentukan karakter di pesantren ini dilaksanakan dalam 3 kegiatan rutin yakni kegiatan harian, kegiatan mingguan dan kegiatan bulanan. Adapun karakter-karakter yang 
paling menonjol dalam pesantren ini adalah sebagai berikut:

\section{Karakter Religius}

Perencanaan

pembentukan

karakter religius di pesantren Manarul Huda telah dimulai sejak penerimaan santri baru. Dalam penerimaan santri baru, pesantren membentuk kepanitiaan yang terdiri dari para guru dan pengurus. Setiap santri baru yang masuk ke Pesantren Manarul Huda Bandung, hampir $60 \%$ berasal dari pulau Jawa, kemudian sisanya berasal dari luar pulau Jawa. Para santri yang akan mendaftar di Pesantren Manarul Huda harus mengikuti beberapa tes antara lain tes bacaan Al-Quran berserta ilmu tajwidnya dan ilmu pengetahuan agama. Hasil dari tes tersebut nantinya akan digunakan untuk menentukan kelas para santri.

Pembentukan karakter religius di Pesantren Manarul Huda dilaksanakan setiap hari dalam berbagai kegiatan. Kegiatan pembelajaran dikelas dilaksanakan setelah selesai sholat fardhu. Pondok pesantren ini adalah tipe Salafiah, sehingga materi yang diajarkan berupa kitab kuning yang harus dihafalkan dan dipahami maknanya oleh para santri untuk kemudian dapat diplikasikan didalam kehidupan sehari-hari.

Evaluasi dalam pembelajaran ini dilaksanakan setiap minggu atau setelah semua materi disampaikan. Tes yang digunakan untuk mengevaluasi hasil pembelajaran ini berupa tes lisan maupun tulisan untuk mengetahui sejauh mana santri menguasai materi yang telah diajarkan. Target yang ingin dicapai dari kegiatan pembelajaran ini adalah santri dapat membaca kitab kuning sesuai dengan kurikulum Salafiah dan bisa mengamalkan isi kitab kuning didalam kehidupan sehari-hari. Selain itu, dalam kegiatan Tartiban (Tanya- jawab dengan Kiyai) yang dilaksanakan dimasjid setiap shalat Ashar, para santri juga dites hafalan kitab kuningnya oleh kiyai secara langsung.

Selain melalui kegiatan pembelajaran dikelas, karakter religius juga dibentuk melalui pembiasaanpembiasaan kegiatan sehari-sehari dimulai sejak santri bangun tidur hingga menjelang tidur. Setiap hari para santri dibiasakan untuk bangun pukul 02.30 WIB untuk melaksanakan Shalat Tahajud. Kegiatan ini melatih mental santri untuk bangun pada malam hari dan beribadah lebih khusyu'. Kemudian dilanjutkan dengan kegiatan sholat Subuh berjamaah. Pada pagi harinya sekitar pukul 08.30 WIB - selesai, para santri dibiasakan untuk mengerjakan sholat Dhuha. Kegiatan ini dimaksudkan agar para santri terbiasa mensyukuri segala nikmat yang telah diberikan oleh Allah SWT. Sholat fardhu berjamaah menjadi agenda wajib yang harus diikuti setiap santri yang tidak berhalangan untuk mengokohkan karakter Ukhuwah Islamiah. Setelah selesai melaksanakan sholat Magrib, semua santri dibiasakan untuk melakuka kegiatan wirid agar senantiasa mengingat Allah SWT dalam dzikir.

Dalam program kegiatan mingguan, pembentukkan karakter religius dilaksanakan dalam kegiatan puasa sunah, Istighosah dan membaca surat Yasin. Kegiatan puasa sunnah merupakan kegiatan mingguan yang rutin dilaksanakan pada hari Senin dan Kamis. Kegiatan ini selain sebagai pembiasaan keagamaan juga sebagi latihan untuk para santri agar memiliki sifat sabar. Kegiatan Istighosah dilaksanakan dimasjid setelah sholat magrib pada malam Jumat. Kegiatan ini berupa ceramah singkat kiyai yang berisi nasihat-nasihat untuk para santri. Kemudian dilanjutkan dengan kegiatan 
pembacaan surat Yasin setelah sholat Isya. Kegiatan ini bertujuan untuk mengirim doa kepada orang yang telah wafat serta, melatih mental para santri untuk membiasakan membaca AlQuran.

Setiap satu bulan sekali, para santri Pesantren Manarul Huda rutin melaksanakan kegiatan berjanji. Kegiatan berjanji adalah kegiatan mengagungkan Rasulullah SAW melalui shalawat. Kegiatan berjanji ini dilaksanakan setiap malam minggu pada minggu kedua setiap bulannya. Kegiatan ini bertujuan agar para santri dapat lebih mengenal dan dapat meneladani sifat Rasulullah SAW.

\section{Karakter Mandiri}

Salah satu misi dari pesantren Manarul Huda adalah membentuk karakter santri yang mandiri. Karakter mandiri tersebut tercermin dalam kegiatan para santri sehari-hari yang dibiasakan untuk memenuhi kebutuhannya sendiri tanpa bantuan orang tua. Setiap santri yang masuk di pesantren ini tidak dikenakan biaya apapun atau gratis sebab para pengurus pesantren berharap agar para santri tidak membebani orang tua dalam menuntut ilmu. Bahkan, pesatren memiliki program keahlian khusus agar santri memiliki kemandirian ekonomi.

Perencanaan program keahlian di pesantren Manarul Huda terdiri dari program kewiraushaan, pertanian dan peternakan. Program-program tersebut bertujuan untuk melatih bakat dan untuk memenuhi kebutuhan para santri. Setiap hari Jumat, para santri mendapatkan waktu libur sehingga mereka dapat fokus pada pekerjaannya masing-masing. Santri dituntut bekerja secara gigih untuk membekali hidup mereka setelah lulus dari pesantren.
Program kewirausahaan pesantren bergerak dibidang penjualan galon dan makanan. Program kewiraushaaan dipesantren Manarul Huda Bandung tergolong unggul, sebab tingkat penjualan galon cukup tinggi. Selain itu, para santri perempuan diajarkan untuk membuatan berbagai olahan makanan seperti kue, gorengan, snack dan lain-lain yang kemudian dijual dikantin pesantren atau dijual berdasarkan permintaan konsumen. Program pertanian dan program peternakan sampai saat ini masih didonimasi oleh santri laki-laki. Para santri laki-laki dibentuk menjadi dua kelompok sesuai minat dan bakatnya. Kelompok santri yang masuk dalam program pertanian bertugas menanam sayur-sayuran dikebun. Sedangkan kegiatan kelompok santri dalam program peternakan adalah beternak ayam. Kemudian, semua penghasilan dari program-program tersebut akan dibagi rata untuk semua anggotanya.

Hasil dan pembahasan dapat disajikan menggunakan sub judul sesuai kebutuhan. Hasil dan pembahasan berisikan data yang dikumpulkan selama proses penelitian serta analisis dari data tersebut. Setiap argumen harus dikaitkan dengan kajian pustaka pada bagian pendahuluan. Bagian ini tidak berisikan kutipan dari sumber-sumber lain. Bagian ini hanya berisikan analisis penelitian dan pendapat peneliti terhadap hasil penelitian.

\section{SIMPULAN}

Pendidikan karakter dipesantren Manarul Huda Bandung dilakukan melalui metode pembiasaan dalam bentuk kegiatan harian, kegiatan mingguan, dan kegiatan bulanan. Kegiatan harian yaitu kegiatan pembelajaran dikelas, dan kegiatan dalam aktivitas sehari-hari seperti sholat 
Dhuha, sholat Tahajud, wirid, dan tartiban. Kegiatan mingguan yaitu pasa sunnah Senin dan Kamis, Riyadhoh, Istighosah, dan membaca surat Yasin pada malam Jumat. Kegiatan bulanan yaitu berjanji dengan mengagungkan Rasulullah melalui shalawat nabi.

Pendidikan Karakter yang paling menonjol di Pesantren Manarul Huda ini adalah menanamkan karakter religius dan karakter mandiri. Karakter religius ditanamkan melalui rutinitas sehari-hari santrinya dimulai sejak bangun tidur hingga menjelang tidur. Pesantren ini juga memiliki program-program keahlian seperti kewirausahaan, pertanian, dan peternakan sebagai upaya mengembangkan karakter kemandirian para santri.

\section{REKOMENDASI}

Penelitian ini
direkomendasikan pada $\begin{array}{r}\text { sangat } \\ \text { peneliti } \\ \text { selanjutnya untuk dapat menggali }\end{array}$
kembali karakter-karakter lain yang bisa
diteliti dari proses pengajaran di
Pesantren Manarul Huda, Bandung.
Selain itu, hal lain yang perlu
diperhatikan untuk diteliti pada
penelitian selanjutnya adalah terkait
proses evaluasi dalam pendidikan
karakter di pesantren sebab suatu
sistem pendidikan yang baik
memerlukan evaluasi agar tujuan
pendidikan tersebut dapat tercapai
secara maksimal.

\section{DAFTAR PUSTAKA}

[1] I. Syafe'i, "PONDOK PESANTREN?: PENDAHULUAN Pondok pesantren yang melembaga di masyarakat , terutama di pedesaan merupakan salah satu lembaga pendidikan Islam tertua di Indonesia. Awal kehadiran Boarding School bersifat tradisional untuk mendalami ilmu-ilmu agama Isl," Al-Tadzkiyyah, vol. 8, no. I, pp. 6182, 2017.

[2] S. A. Siradj, "Islam kebangsaan: fiqih demokratik kaum santri," Pustaka Ciganjur, 1999.

[3] B. Ryan, Kevin, "Building Character in Schools: Practical Ways to Bring Moral Instruction to Life," 1999.

[4] S. Arikunto, Prosedur Penelitian Suatu Pendekatan Praktik. Jakarta: Rineka Cipta, 2010.

[5] R. Megawangi, "Pendidikan Karakter Solusi Yang Tepat Untuk Membangun Bangsa," Indones. Herit. Found., 2004.

[6] L. Thomas, "Educating for character: How our schools can teach respect and responsibility," Bantam Books, 1991.

[7] K. R. Bohlin, E. Karen., Deborah Farmer, "Building Charater in School Resource Guide, San Fransisco, Jossey Bass.," 2001.

[8] D. P. K. K. Zubaidi, "Aplikasinya dalam Lembaga Pendidikan," 2011.

[9] M. F. Gaffar, "Pendidikan Karakter Berbasis Islam (Disampaikan pada Workshop Pendidikan Karakter Berbasis Agama)," 2010.

[10] U. Sanusi, "Pendidikan kemandirian di Pondok Pesantren," J. Pendidik. Agama Islam - Ta'lim, vol. 10, no. 2, pp. 123-139, 2012.

[11] H. M. Arifin, Imu pendidikan Islam: suatu tinjauan teoritis dan praktis berdasarkan pendekatan interdisipliner. 1996.

[12] A. F. Ubaidillah, "Pembentukan Karakter Religius dan Mandiri Melalui Model Pendidikan ala Pondok Pesantren," AL-WIJDÁN J. Islam. Educ. Stud., vol. I, no. 1, pp. 
1-12, 2016.

[13] S. Sofyani, H., Ulum, I., Syam, D., \& Wahjuni, "Islamic social reporting index sebagai model pengukuran kinerja sosial perbankan syariah (studi komparasi Indonesia dan Malaysia).," vol. 4, no. 1, 2012.

[14] M. I. Soelaeman, "Suatu Telaah tentang Manusia-ReligiPendidikan," Depdikbud, 1988.

[15] Masrun, "Faktor-Faktor yang mempengaruhi Kemandirian Pada Remaja," 1986.

[16] A. A. Gea, "Character Building 1 Relasi dengan Diri Sendiri (edisi evisi)," p. 195, 2003.

[17] A. Ali, M. M, "Psikologi Remaja Perkembangan Peserta Didik," Bumi Aksara, 2004.

[18] P. Sugiyono, Memahami Penelitian Kualitatif. 2005. 